\title{
The legal system of tax income and tariff revenue in the natural resources and mining sector of Uganda: obstacles and challenges in collecting taxes, duties, parliamentary and judicial control
}

\author{
Gloria Kembabazi and John Osapiri*
}

\begin{abstract}
This paper examines the legal foundations of taxation of minerals examining legal provisions concerning natural resources generally and, mining as a sector - with oil and gas as one of the emerging sub-sectors for regulation. The paper examines the challenges and offers potential solutions with a view that economic policymaking is critical and the legal and policy framework must be critically structured and carefully implemented to allow for maximum government revenue and positive natural resource governance.
\end{abstract}

\section{A. Introduction}

Natural Resources are everything existing on the earth that we did not put there including forests, animals, marine, geological, atmospheric and even human resources. What makes something a resource is that it is useful to us as humans particularly in an economic sense. Resources are therefore resources because we use them for our survival especially in terms of economic benefit. Governments particularly gain economic value from resources within their territorial boundaries by imposing taxes and royalties on the extraction, exploitation and use of natural resources deemed taxable. This paper focuses on taxation of the mining or mineral industry as one of the special taxable categories of natural resources in Uganda and picks some lessons from the oil and gas sector given its current emergence on the Uganda scene. Otherwise, it would be impossible to reflect all the various taxation regimes and specific challenges for each taxable natural resource category.

Uganda as a country is well endowed with natural resources both in the form of renewable and non-renewable resources, the mining sector being primarily non-renewable due to the nature and occurrence of minerals from their geological formation. Mineral occurrence in Uganda ranges from gold, graphite, copper, lead, cobalt, nickel, iron ore, tin, and a

* The authors are Ugandan lawyers with specialisation in regional integration. They each hold LLB (UCU/NU), PgDLP (LDC), and LLM (UDSM) and can be reached on glorinice@yahoo.com and osapirijohnldp12@gmail.com, respectively. Gloria is currently a trainee at the European Investment Bank, Luxembourg in the Operations Directorate -Africa Public Sector Division. John is a legal officer (mediation, legal research and investigations) at Uganda Lands Commission of Inquiry and a lecturer at School of Law, Nkumba University, Uganda. 
variety of gemstones. ${ }^{1}$ Dating back to almost 100 years ago, Uganda was mapped and investigated for its geological mineral composition. ${ }^{2}$ Since then, some zones of the country have been exploited to contribute to the country's economic development as well as the livelihood of the artisanal miners. From these activities taxation is imposed or at least foreseen by the government as a great and potential source of revenue. Despite that, there is still a sense that there are some parts of Uganda that remain under-explored but that has not hindered the legal system of taxation from evolving and taking shape to its present form.

\section{B. Background on the legal system of tax income and tariff revenue in the natural resources and mining sector of Uganda}

The Constitution of Uganda provides in its objectives that the State shall protect important natural resources, including land, water, wetlands, minerals, oil, fauna and flora on behalf of the people of Uganda. ${ }^{3}$ The Constitution further prescribes that Parliament shall make laws regulating the exploitation of minerals, the sharing of royalties arising from mineral exploitation, and the conditions for payment of indemnities arising out of exploitation of minerals. ${ }^{4}$ The natural resources and mining sectors are therefore subject to the taxes levied by government.

It is no secret that since the early years of the millennium as early as $2000 / 2001$ the mining sector has been accorded a high priority status in the national development plans of Uganda. To this extent Uganda had in place a mineral policy (old policy) whose institutional framework was structured under the Ministry of Energy and Mineral Development with a specific directorate on energy and mineral development with three technical departments namely; energy resources, petroleum exploration and production and mineral resources. ${ }^{5}$ The old policy had as one of its objectives, the commitment to ensure that mineral wealth supports national economic and social development. ${ }^{6}$ This objective was to be attained through the principle that government shall ensure equitable sharing of revenue from mineral resources by a strategy of levying and collecting royalties and fees for services rendered with a stipulation that those royalties should be shared between the central government and local governments from where minerals are produced. ${ }^{7}$ This particular aspect is

1 Mining and Mineral Policy for Uganda. Ministry of Energy and Mineral Development, 2018 Pg. 13 to 14 .

2 http://www.bgs.ac.uk/research/international/dfid-kar/WC94001_col.pdf [Last Accessed on 24th November 2018].

3 The Constitution of the Republic of Uganda 1995 (as amended), Objective 8.

4 Ibid., Article 244.

5 Mineral Policy (Old Policy) of Uganda Ministry of Energy and Mineral Development September 2000 Pg. 10.

6 Ibid., The Mineral Policy of Uganda (Old Policy): Objective 2, Pg. 19.

7 The Mineral Policy of Uganda (Old Policy): Objective 2, Pg. 19. 
further developed in Uganda's natural resource governance strategy in various ways including revenue management strategies for the oil and gas sector.

The old policy also had the objective of stimulating investment in the mineral sector by promoting private participation. For the attainment of this objective the principle was to acquire basic geo-scientific data, disseminate it and put in place a stable, predictable, and competitive fiscal and legal environment for the sector with a strategy of instituting and maintaining a progressive and predictable tax regime with well-defined parameters. ${ }^{8}$ It is worth noting that these two objectives had both been prioritised for implementation in the short term. Whether that has been achieved or not, is explored throughout this paper by examining the current trends evidenced through the new policy and examining the current legal system of tax income and tariff revenue in the natural resources and mining sector of Uganda.

\section{Legal framework of tax administration in Uganda}

The legal system of tax income and tariff revenue of natural and mineral resources is enshrined in legal texts starting right from the Constitution, to statutes, as well as in policy frameworks. All these guide judicial practice that follows parliamentary legislation. Within this legal system, various organs and agencies of government perform roles prescribed by law and policy towards achieving resource governance for the benefit of all, particularly in terms of taxation and revenue collection, adjudication and administration.

The Constitution stipulates that it is the duty of every citizen to pay taxes to the government. ${ }^{9}$ Further, the Constitution provides that no tax shall be imposed except under the authority of an Act of Parliament and that all taxes, revenues, duties and other monies collected are to be paid into the Government Consolidated Fund. ${ }^{10}$

The Constitution empowers Parliament to legislate (make laws) in relation to administration and collection of taxes. Pursuantly, several laws have been enacted including; the Income Tax Act, Value Added Tax Act (VAT), the Excise Duty Act, Stamp Duty Act and, the Tax Procedure Code Act. Most tax laws are regularly revised. For instance, the Income Tax Act is revised annually to coincide with the fiscal year and budgetary planning. In addition to statutes, several other instruments guide the legal system of tax income and tariff revenue including Practice Notices issued by the Commissioner General of the Uganda Revenue Authority (URA).

The Uganda Revenue Authority Act establishes the URA as the institution mandated with administration, assessment, collection and accounting for Taxes. ${ }^{11}$ URA is a body corporate, headed by the Commissioner General and supervised by the ministry of finance.

8 Mineral Policy Pg.18.

9 The Constitution, Article 17 (g).

10 Ibid., Article 152 (1).

11 Uganda Revenue Authority Act, Cap 196. 
URA is therefore the overall government agency for tax administration matters in Uganda. In conjunction, the Tax Appeals Tribunal is mandated with hearing tax disputes and reviewing decisions of the Commissioner General on Tax matters. It hears tax matters as a first instance tribunal.

\section{Policy framework of the mining sector}

Uganda's current Mining and Mineral policy was approved in May 2018 and as such it is still very new. ${ }^{12}$ The overall goal of the mining and mineral policy for Uganda is to develop the mining industry through increased investment, value addition, national participation and revenue generation to contribute significantly to socio-economic transformation and poverty eradication. ${ }^{13}$ The vision and the goal of the policy are intrinsically linked given that the vision of the policy is to have a transformed mineral sector for the socio-economic development of Uganda.

\section{Mining Policy objective}

The policy sets out specific objectives, guiding principles and corresponding strategic interventions towards attainment of the overall goal of the policy with some aspects dedicated to revenue matters. The objective relevant to natural resources taxation is to ensure efficient, equitable, accountable and transparent management of mineral revenues. ${ }^{14}$ The guiding principle related to achieving this objective is to promote transparency, accountability and public participation in management of mineral revenues for improvement of livelihoods, creation of jobs, effective technology transfer and generation of significant income for sustainable development of the country. ${ }^{15}$

The corresponding strategy towards achieving this objective is to develop and implement a stable, transparent, predictable and competitive fiscal regime for efficient management of mineral concessions and allocation rights. This calls on the need for provision of mechanisms for transparency by easing access to information mainly through ICT, automation of business processes to enhance efficient, effective and transparent concession and mineral rights issuance. ${ }^{16}$

$12 \mathrm{http} / /$ www.oilinuganda.org/mining/relief-for-asms-as-cabinet-approves-the-new-mining-policy.ht $\mathrm{ml}$ [Last Accessed December 1st 2018].

13 Mineral Policy 2018 Pg. 19.

14 Mineral Policy 2018, Objective 2, Pg. 19.

15 Ibid., Pg. 20.

16 Ibid., Pg. 22. 


\section{Institutional mechanisms for the mining sector}

There is a framework to provide for various institutions for the proper implementation of the policy goals. The mining and mineral specific institutions discussed hereunder complement the general tax institutions already discussed before. Some of the institutions forecasted are specifically tailored to revenue related matters. The Directorate of Geological Survey and Mines (DGSM) is specifically set up with Units, considered as requisite specialised agencies, to handle specific matters.

The Mineral Audit Agency is charged with various roles relating to revenue and tax. For example among some of its responsibilities include the following; the assessment and collection of right taxes and royalties payable to Government from minerals produced, processed and exported; counteracting minerals smuggling and royalty evasion; revenue distribution and management; advising on competitiveness of Uganda's mining environment with the aim of enhancing control and compliance, ensuring maximum collection of revenue and securing national interests. ${ }^{17}$ These responsibilities when scrutinised reveal that the Mineral Audit Agency plays a critical role in Uganda's realisation of natural resource governance in the mining sector. Particularly the Agency also brings to account the various roles played by other institutions is levying, collecting and administering tax and other revenue.

Closely related and complementary to the Agency is the Mining Tribunal. The role of the Mining Tribunal will be to arbitrate mineral and mining disputes. ${ }^{18}$ Once set up this proposed Tribunal will contribute to access to justice in the mining sector and further promote transparency for both government, citizens and other players in the sector. It is indeed one of the key reforms of the new policy. It therefore remains to be seen what co-operation and coordination the Mining Tribunal and the Tax Appeals tribunal would have to ensure smooth operation between the two bodies as regards tax and revenue related matters in the mining sector.

The Ministry of Finance, Planning and Economic Planning is the government ministry charged with the macroeconomic stability of the country. In relation to the mining and mineral policy, it plays significant roles that include ensuring appropriate management of revenue from the mining industry, designing fiscal regimes and other fees and charges applicable to the mining industry in consultation with the DGSM, promoting the financing of Ugandans to participate in the mineral sector, and monitoring and assessing the impact of mineral revenues on the economy. ${ }^{19}$

The Uganda Revenue Authority (URA) is also a critical player in the tax income and revenue system of Uganda as the overall government agency for tax assessment, collection, and administration. The role of the URA is to assess and collect specified revenue, adminis-

17 Ibid., Pg. 30.

18 Mineral Policy 2018, Pg. 31.

19 Ibid., Pg. 31. 
ter and enforce taxation laws and ensure tax compliance. Specific and relevant roles of the URA prescribed by the policy include working with DGSM to collect revenue specified in the Mining Act, and reporting on the collection of tax and non-tax revenue from the mineral sector. ${ }^{20}$ It is not yet clarified as to whom the reports would be directed, whether as an interinstitutional or public report or even both ways.

The role of the Auditor General is also important towards the tax income and tariff revenue of Uganda. The function of the Auditor General is to audit and report on the public accounts of Uganda and further, to conduct financial and value for money audits in respect of any project involving public funds. The relevant specific roles of the Auditor General under the Mining and Mineral Policy include providing an independent oversight of Government mineral operations through financial and other management audits in accordance with the constitutional provisions and any other relevant legislation, and ensuring adherence to national and international accounting standards in the mining industry. ${ }^{21}$ This would complement and augment the role of the Mineral Audit Agency, a new introduction by the current policy.

Local governments are also critical in the legal system of tax income and tariff revenue of Uganda. Most pertinent is the Local governments' role in licensing building minerals such as sand, clay and murram. ${ }^{22}$ This is especially important as this category of commercial substances are excluded from the definition of minerals in the Constitution despite being a viable source of revenue to the government.

It is envisaged that for the implementation of this policy there should be a monitoring and evaluation strategy to track action and progress. This means that there needs to be a commitment towards building and strengthening the institutional capacity of aspects including geoscience data collection and management, mineral exploration, mining tax administration and collection frameworks, governance, licensing, regulation and enforcement, artisanal and small scale mining, and environmental management. The policy framework therefore recommends that the Government should strengthen the capacity of DGSM to inspect, monitor and audit mineral operations; promote mineral beneficiation and value addition; promote the collection and distribution of mineral revenue; establish a transparent and competitive licensing regime; ${ }^{23}$

What is even more pertinent if not revolutionary is that the reformatory policy envisages and recommends the establishment of a Mineral Reserve Fund to store mineral revenues for creation of a permanent source of wealth as a provision for intergenerational equity. ${ }^{24}$ If the fund is created, it would be a commitment towards utilisation of revenue benefits in a progressive manner. This is especially so for host communities that could draw from

21 Mineral Policy 2018, Pg. 37.

22 Ibid., Pg. 38.

23 Ibid., Pg. 40.

24 Ibid., Pg. 43. 
this fund at the decline of a mineral reserve to restore the area from the environmental effects of mining processes, for instance. Another quicker benefit would be utilising the fund for socio-development projects. At this stage it also remains unclear how this Fund would operate outside the Consolidated Fund in which all government revenues are deposited pursuant to the Constitution but one can suppose that it would create a reserve as the name suggests.

\section{E. Tax income and tariff revenue in natural resources, mining sector, and oil and gas sector of Uganda}

Uganda imposes domestic tax on both income and consumption. Income tax is imposed as a direct tax on a person's net income over a tax period. From a policy perspective, income tax is imposed on every person with chargeable income for a year. ${ }^{25}$ For natural resources, the focus shall be taxes as regards Petroleum operations that is to say production of crude oil or natural gas and delivery of the same at the delivery point under a program of regulation production and sale. For the minerals sector it falls on similar aspects and is also covered in the legal regime explained below.

Consumption tax is imposed under the VAT regime at the time of transaction and operates as an indirect tax either on expenditure relating to the consumption of goods and services at the last point of sale to the final consumer or on intermediate transactions between businesses. VAT is imposed in the country of destination or where goods and services are consumed or destined for consumption. VAT is a tax on consumption imposed on the supply of goods and services. ${ }^{26}$

Taxation of mining operations is specified under the Income Tax Act. The income tax rate applicable to mining companies falls on a lower threshold of $25 \%$ and an upper threshold of $45 \%$ according to the formula set out in the $3^{\text {rd }}$ Schedule. ${ }^{27}$ The Income Tax Act is to the effect that the rate of income tax applicable to a licensee in respect of mining operations is the rate specified under the third Schedule on rates for licensees and contractors. ${ }^{28}$ It is therefore to the effect that Income Tax Rate applicable thereunder is 30\%. Contractors and subcontractors are subject to tax and in case of inconsistence in the taxation regime thereof, in respect of mining operations, the relevant part of the Income Tax Act and the petroleum, agreement shall prevail. ${ }^{29}$

There are some deductions relating to mining operations specified under the Income Tax Act. ${ }^{30}$ Allowable deductions include; decommissioning cost reserve and decommis-

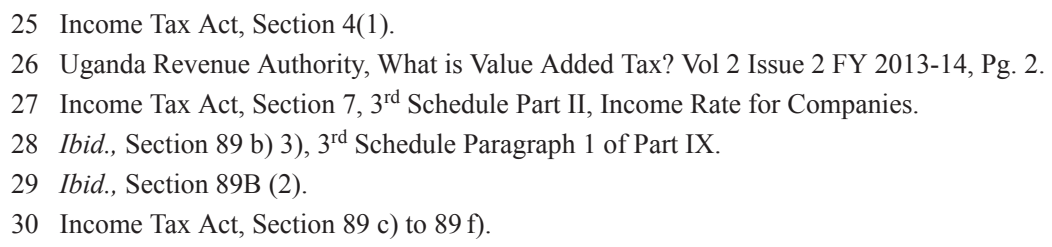


sioning expenditure, allowable contract expenditures, and transfer of interest in a petroleum agreement. In contrast, capital gains tax is payable and exemplary; Uganda won a case of USD 434m against heritage oil arbitrated through the United Nations Commission on International Trade Law (UNCITRAL) in London. This matter had come up in the Ugandan courts and been decided similarly before the international tribunal's decision. ${ }^{31}$

More specifically, a deduction is allowed for any expenditure of a capital nature incurred in searching for, discovering, testing, or winning access to deposits of minerals. ${ }^{32}$ There are also deductions allowed in the context of depreciable assets and industrial buildings. ${ }^{33}$ For plant and machinery used in farming, manufacturing and mining operations, it is capped at $30 \% .^{34}$

Furthermore, some goods are exempt from custom duties, under the East African Community framework, at importation; but attract $18 \%$ VAT when sold locally. There is an exemption for licensed companies on machinery, spares and equipment used in oil, gas and mining operations. ${ }^{35}$

The rate of income tax applicable to a licensee in relation to petroleum operations is $30 \% .{ }^{36}$ The rate for a non-resident contractor under section $89 \mathrm{GG}$ is $10 \%$. ${ }^{37}$ Part IX A is on the Income Tax rate for resident contractors. The income tax rate payable on a participation dividend paid by a resident contractor to a non-resident company is $15 \%{ }^{38}$ There are deductions that are provided as relating to petroleum operations and these are; deductions in regards to Petroleum Exploration expenditure, cost of petroleum development expenditure, and the costs for decommissioning. ${ }^{39}$

\section{F. Obstacles and challenges in collecting taxes and duties}

One of the challenges faced in collecting revenue from the mineral subsector is that the sector is under-developed. There is limited exploitation of the mineral wealth in Uganda. This maybe a result of the nature of artisanal mining where by poor or no business, financial or employment records are kept and as such accountability is difficult to attain. A non-existent company cannot pay taxes. Despite $19.4 \%$ average growth rate of the sector, its contribution to the national economy remains minimal..$^{40}$ That is not to say that all is lost, as rev-

31 Heritage Oil Uganda and Uganda Revenue Authority (TAT No. 20/2010).

32 Ibid., Section 36.

33 Ibid., Section 27 and 29.

34 Ibid., $6^{\text {th }}$ Schedule, Part I, Class 3.

35 East African Community Customs Management Act, $5^{\text {th }}$ Schedule, Part B General Exemptions No. 30.

36 Income Tax Act, 3rd Schedule, Part IX, Paragraph 2.

37 Ibid., Section $89 \mathrm{~g})$.

38 Ibid., Section 89 h), 9(2).

39 Ibid., Sections 89GB, GC and GD.

40 Mineral Policy 2018 Pg. 12. 
enues from license fees and royalties increased from US\$0.5 million in 2003 to US\$ 4.14 million in 2016/17. ${ }^{41}$ That means that with better and improved resource governance, revenue from the sector can be expected to grow.

There is also a challenge of minimal revenue collection. This is a direct result of having no value added to the minerals before exportation. Mineral ores in Uganda are largely exported unprocessed depriving the country of employment and revenue. There is need for a strategy that governs value addition to minerals before exportation. ${ }^{42}$ It is therefore important for the country to deeply consider and plan on how to execute mineral processing and beneficiation not just for the immediate increase in revenue from the value but also from the contribution to the wider economy in terms of industrial growth and creation of employment.

Furthermore, some resource substances are excluded from the definition of minerals thereby creating a natural resource governance gap and a revenue leak. The Constitution excludes from the definition of the word 'mineral', sand, stone, clay and, murram. ${ }^{43}$ These minerals if regulated can contribute over $3 \%$ to GDP. ${ }^{44}$ It is therefore not only important to regulate commercial exploitation of these substances but it is also imperative for the increase of revenue generation from this category of minerals for improved socio-economic development. In fact, Uganda's mineral policy vision is a transformed mineral sector for socio-economic development of Uganda. ${ }^{45}$

There is also a challenge of revenue sharing between the central and local governments. When insufficient royalties are disbursed to districts and sub-counties it does not spur longterm social and economic development of mineral host communities. It is even worse when the royalties disbursed to districts, are not put to proper use. There is need for government to develop a mechanism to ensure that the local governments use royalties for health, clean water supply, education, infrastructure development, inspection and monitoring of mining activities. ${ }^{46}$ This would help in correcting any negative attitude towards government. When public services and amenities are availed and decentralised citizens feel that, their contribution towards nation building is being put to good use. As a ripple effect, this may work to motivate more tax compliance from all categories of taxpayers.

Some challenges are broad and relate to tax matters generally and in that way have an impact on taxation of minerals as well. Among these are tax evasion and avoidance. Tax evasion is a big challenge. It refers to the illegal non-payment or under payment of taxes by individuals, corporations, partnerships and trusts. It involves misrepresenting true state of

41 Mineral Policy 2018, Pg. 12.

42 Ibid., Pg.6.

43 Constitution Article 244(5).

44 Baseline Assessment of Development Minerals in Uganda, 2018.

45 Mineral Policy 2018 Pg. 19

46 Ibid., Pg. 15. 
affairs to tax authorities to reduce tax liability. In the case of Uganda Revenue Authority VS Rwakashaija and 2 others ${ }^{47}$ the issue of tax evasion was debated.

Tax Avoidance is yet another challenge, closely related to tax evasion but distinct. Tax avoidance is the legal use of tax laws to reduce ones tax burdens. It is also a form of tax non-compliance however is not illegal as it may simply take the form of arranging ones tax affairs to incur the least tax-burden possible. For instance in the case of Standard Chartered Bank (U) Ltd and 6 others v. The Commissioner General Uganda Revenue Authority, ${ }^{48}$ it was held that the recapitalization scheme by the bank was a tax avoidance strategy.

There is some progress being made towards addressing some of these challenges. For instance, URA has been transitioning into digitisation of the tax payment system. Attaining a high level of digitisation reduces bureaucracy and provides improved and harmonised records management and access. With improved access comes more knowledge and understanding of the tax system as well as responsibility on the taxpayer to comply with his, her or its obligations thereby promoting tax transparency and curbing on the incidences of under declaration of one's tax burden.

\section{Impact and challenges of oil and gas in the natural resource governance of Uganda}

Oil and gas is a recently fast-tracked natural resource in Uganda. Uganda has been undertaking exploration of the oil resources and is at the verge of commencing production, in fact it was expected to start in 2018 but as of yet there has not yet been a formal announcement from government on whether production has commenced. The legal framework for oil and gas is quite distinct from the mining sector as oil and gas is taken as a sector of its own.

There are problems associated with this such as loss of arable land due to fertility of soil being impacted by the exploration and extraction processes, pollution affecting the natural pre-existing eco-system, social conflict leading to unrest and violence that can escalate to political instability, diseases, and poverty (the dutch disease). Uganda should be careful and keen on preventing some of these problems by taking lessons from older oil producing countries.

Indeed one of the steps the country has put in place is the Oil and Gas Revenue Management Policy. ${ }^{49}$ A great policy especially when contracted with the Mineral Reserve Fund recommended by the mineral policy. This suggests that there is a harmonisation of policies across natural resources governance in the country. The Policy recognises that oil and gas resources are finite but provide immense revenues and therefore that there is a need to manage that revenue in a manner that encourages other sources of wealth creation and

47 Civil Appeal No. 5 of 2007.

48 HCCS NO. 63 OF 2011.

49 Oil and Gas Revenue Management Policy, Ministry of Finance, Planning and Economic Development, Feb 2012. 
providing a mechanism for sharing of royalty revenues with the local governments within the oil producing region.

\section{G. Parliamentary and judicial controls as a solution to the challenges}

Parliamentary controls are the tax laws in place to guide tax income and tariff revenue administration and collection while judicial control is the judicial process established in the law to be followed for remedy in case of any dispute. In a sense, parliamentary and judicial controls merge and as a result often work together in providing a solution.

The Tax Appeals Tribunal is the first court of instance for tax disputes. It provides a specialised forum for the resolution of disputes. The establishment of the Tax Appeals Tribunals by parliament introduced a quicker access to justice in the face of case backlog in ordinary courts. The procedure to follow upon an apparent default on remission of taxes is laid down by Parliament in the law. The judicial procedure to follow takes into consideration both instances of default, for the tax collector or grievance on the part of a taxpayer.

A taxpayer who is aggrieved with or dissatisfied with a tax decision first objects to the decision to the commissioner General of URA. The commissioner then makes an objection decision allowing or disallowing the objection in part or wholly. A Tax payer who is not satisfied with the decision of the Commissioner General, then appeals to the Tax Appeals Tribunal, the quasi-court of first instance for tax disputes. This does not negate the unlimited Jurisdiction of the High Court in all matters. Therefore, the nature of the dispute may determine whether the tax decision is appealable to the Tribunal or the High Court. ${ }^{50}$

The Tax Appeals Tribunal then reviews the tax decision made by the Commissioner General and may affirm, vary or set-aside the tax decision. A party dissatisfied with such a decision may appeal to the High Court against the Tribunal's decision given that the High Court is vested with appellate jurisdiction in tax matters. ${ }^{51}$ One can Appeal from the High Court to the Court of Appeal and then to the Supreme Court, which is the final appeal court in Uganda, except where the second right of appeal has been exhausted. Persons appearing before the Tribunal must have the requisite legal qualifications to represent a party.

\section{Conclusion}

Tax revenue is the central benefit to a country and the host communities in which resources occur. The overall opportunity lies with the host country to promote economic development through legal systems that guide and govern taxation and revenue collection and administration obtained from the activities related to natural resource exploitation such as mining. Scholars recommend that fiscal terms for the mining and oil and gas sector must be robust in the face of changing circumstances. Such fiscal terms should be progressive, stable, cred-

50 Okuja J, 'Taxation of Income and Consumption in Uganda, 1st Edition 2016, P.14. Also Section 25 of the Tax Procedure Code Act, Act 14 of 2014.

51 Ibid., Tax Procedure Code Act, Section 25(2). 
ible, rely on observable and verifiable data, minimise opportunities for aggressive tax planning, provide government with a revenue stream in all production periods, avoid specialised incentives, and aim for minimal discretionary and negotiated elements. ${ }^{52}$ It is therefore critical for Uganda to continue developing its legal system of income tax and tariff revenue towards attaining economic development and minimising losses.

52 Philip Daniel, 'Natural Resource Taxation: Challenges in Africa.' Fiscal Affairs Department International Monetary Fund Management of Natural Resources in Sub-Saharan Africa Kinshasa Conference, March 22, 2012. 